\title{
EL GOBERNADOR LUIS DE UNZAGA (1717-1793). PRECURSOR EN EL NACIMIENTO DE LOS EE. UU. Y EN EL LIBERALISMO
}

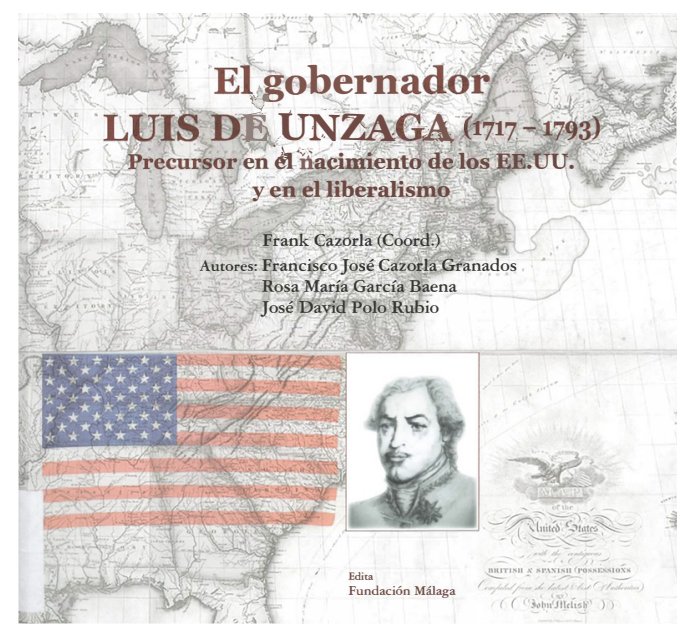

Título: El gobernador Luis de Unzaga (1717-1793). Precursor en el nacimiento de los EE. UU. y en el liberalismo

Autor: Frank Cazorla (coord.)

Editorial: Fundación Málaga

Año de edición: 2019

ISBN: 978-84-09-12410-7
F I diccionario de la RAE define al historiador con una sencilla fórmula: «Especialista en historia». Mucho más extensa y explícita es la definición de historia a la que nos remite, con múltiples y variadas acepciones; si atendemos a las tres primeras, historia es la «narración y exposición de los acontecimientos pasados y dignos de memoria, sean públicos o privados», pero también lo es la «obra histórica compuesta por un escritor», así como la «disciplina que estudia y narra cronológicamente los acontecimientos pasados».

Los autores del libro que hoy comentamos, El gobernador Luis de Unzaga (1717-1793). Precursor en el nacimiento de los EE. UU. y en el liberalismo, son historiadores no solo por su formación en esa disciplina a la que alude la RAE en su diccionario, sino por ser especialistas en ella. Francisco José Cazorla Granados, Rosa María García Baena y José David Polo Rubio son doctores (los dos primeros) y licenciados en Historia por la Universidad de Málaga, y han puesto todo su saber y su experiencia en una minuciosa investigación, que ha durado varios años y les ha llevado a recorrer múltiples archivos y bibliotecas, para contar la historia de un personaje singular para España y América y, sobre todo, para recuperar su figura de un olvido injusto. Nos referimos, se refieren, a Luis de Unzaga y Amézaga, nacido y fallecido en la ciudad de Málaga en el siglo XVIII.

La obra de estos tres autores tiene un marcado carácter histórico que trasciende más allá de las fronteras de una mera biografía del personaje para convertirse, por un lado, en una historia familiar. Así, a lo largo de su extenso y detallado estudio, el trío coordinado y dirigido por Francisco Cazorla nos relata los antecedentes familiares, pero también la huella que deja don Luis de Unzaga a través de su numerosa descendencia; además de analizar las relaciones colaterales, gracias a la familia Saint Maxent, en las que destaca la figura de Bernardo de Gálvez, su cuñado y sucesor tanto en el gobierno del extenso territorio de la Luisiana como en el apoyo a las trece colonias.

Por otro lado, el análisis y descripción de su carrera militar y en la administración lleva al lector a conocer aspectos históricos de la política española en el continente americano. En momentos tan delicados como los 
inicios de la revolución de las trece colonias contra su metrópoli europea, surge la figura del gobernador de la Luisiana (Luis de Unzaga) como elemento de enlace con los patriotas americanos para hacerles llegar las primeras ayudas españolas, siempre siguiendo las órdenes de la corona. Los autores se detienen en este episodio, reivindicando el papel de su biografiado en la independencia americana.

Su papel en el campo social y cultural, en uno y otro continente, así como su preocupación por la mejora en estos ámbitos de su tierra natal, son también objeto de atención para los autores. Fruto de su interés y minuciosidad, el libro nos descubre aspectos hasta ahora desconocidos -o, al menos, bastante inadvertidos u olvidados- de la historia malagueña del último cuarto del siglo XVIII. El paso de Luis de Unzaga, al final de su vida, por los cargos de gobernador militar de Málaga y presidente de la Real Junta de Obras del Puerto de dicha ciudad es descrito por los autores, destacando el interés de aquel por sus subordinados y su ciudad.

Todo ello lo puede encontrar el lector en una obra organizada en tres partes bien diferenciadas: «Los orígenes del malagueño don Luis de Unzaga», "Luis de Unzaga Amézaga: la figura del precursor» y «Sociabilidad y redes de influencia. El tejido familiar y económico de los Unzaga en Málaga». En ese apretado recorrido por las más de 230 páginas que la Fundación Málaga ha dado a la luz en una cuidada edición, nos encontramos con la descripción de sus antecedentes familiares, en los que dedican especial atención a la figura de su padre: Francisco de Unzaga Amézaga y Aperribay.

En la segunda parte, que ocupa el grueso de la obra, los autores nos describen los primeros pasos en la carrera militar del biografiado y analizan detalladamente su paso por la Luisiana y su desempeño como gobernador de aquel extenso territorio durante ocho años, en el cual el trío de autores destaca el importante papel de Luis de Unzaga en la ayuda a la independencia norteamericana con aportaciones novedosas e interesantes. Sin olvidar su paso por las capitanías generales de Venezuela y Cuba, cierran este apartado con el análisis y descripción de los cargos ya citados en Málaga antes de tener que retirarse a su casa doblegado por la enfermedad.
La tercera parte completa el círculo de la historia personal y familiar de Luis de Unzaga. La figura de su viuda Isabel de Saint-Maxent y la de sus descendientes nos hacen llegar hasta mediados del siglo XIX, entroncando alguno de ellos con las ideas liberales y la masonería.

Acompañan un excelente aparato crítico y un muy buen apoyo de imágenes, ya sea en forma de láminas o de gráficos; se añaden tres apéndices: temático, topográfico y onomástico. Todo ello consigue que la lectura de este libro sea amena y agradable, al mismo tiempo que instructiva para conocer mejor uno de los personajes malagueños más destacados del siglo XVIII, oscurecido quizás por la desmedida atención que se ha prestado en los últimos años a su cuñado Bernardo de Gálvez.

No podemos cerrar esta reseña sin dejar de destacar la minuciosidad en la investigación previa de los autores, que les ha llevado a localizar y consultar gran número de fuentes documentales en más de veinte archivos, la mayoría nacionales, pero también estadounidenses; así como multitud de referencias bibliográficas que quedan de manifiesto en la extensa bibliografía que cierra el capítulo de fuentes.

Sin embargo, a pesar de esa minuciosidad, hay que señalar que se han dejado fuera de su investigación el Archivo Eclesiástico del Ejército de Tierra, en el cual se encuentran depositados los libros parroquiales castrenses de la plaza de Málaga; en uno de ellos (el 2001) se encuentra la partida de enterramiento de don Luis de Unzaga y Amézaga, que confirma los datos aportados por los autores a partir de lo citado por Marion Reder Gadow en 1989 en su libro Morir en Málaga. Testamentos malagueños del siglo XVIII. La consulta de estas fuentes en el citado archivo quizá permita ampliar nuevos datos sobre este personaje y su familia en una futura reedición de esta obra tan novedosa, interesante e instructiva.
Pedro Luis Pérez Frías Universidad de Málaga (España) 